\title{
Change Factors and the Adaptability of Buildings
}

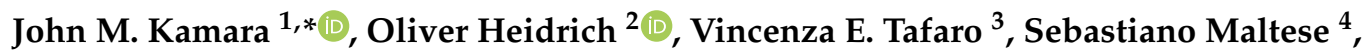 \\ Mario C. Dejaco ${ }^{5}(\mathbb{D})$ and Fulvio Re Cecconi ${ }^{5}(\mathbb{D}$
}

1 School of Architecture, Planning and Landscape, Newcastle University, Newcastle upon Tyne, NE1 7RU, UK

2 School of Engineering, Newcastle University, Newcastle upon Tyne, NE1 7RU, UK; oliver.heidrich@ncl.ac.uk

3 Arcus Consulting, Newcastle upon Tyne, NE28 9NZ, UK; vtafaro@gmail.com

4 Institute for Applied Sustainability to the Built Environment, University of Applied Sciences and Arts of

Southern Switzerland, 6952 Canobbio, Switzerland; sebastiano.maltese@supsi.ch

5 Department of Architecture, Built Environment and Construction Engineering, Politecnico di Milano, 20133-I Milano, Italy; mario.dejaco@polimi.it (M.C.D.); fulvio.rececconi@polimi.it (F.R.C.)

* Correspondence: john.kamara@ncl.ac.uk; Tel.: +44-0191-208-8619

Received: 14 July 2020; Accepted: 12 August 2020; Published: 14 August 2020

\begin{abstract}
The adaptability of buildings addresses the responses of buildings to the changing needs of owners/users and the demands of external factors, over their lifecycle. An understanding of these changes is therefore key to the creation of adaptable buildings. This paper reports research which was aimed at modelling building changes to better understand the challenges for their adaptability. An in-depth study of the changes in selected case studies was conducted to understand the nature, characteristics, and implications of these changes for buildings and their ability to adapt. The findings from these case studies were analyzed against theoretical models reported in the literature on change and adaptability. As a result, a model was developed that identified and categorized a wide spectrum of changes to the building fabric within the broad remit of adaptability that are triggered by many factors, which are sometimes external to the building or organization. In the cases investigated, it was found that the factors that lead to actual changes to buildings were not necessarily due to the ease of making those changes, but rather the organizational will and means to make the changes. Similarly, changes were made not because the building systems were obsolete, but because of non-building factors. The timings of changes therefore did not correspond to the assumed lifespan models of different building layers, suggesting that a new way of predicting and/or categorizing building changes is needed. Furthermore, the interrelationships and nature of the triggers for change suggest that the adaptability of buildings is not just about building systems, but also about non-building factors. Thus, the further exploration of non-building triggers and enablers for change using the developed model presented here, will further enhance the creation of more adaptable buildings.
\end{abstract}

Keywords: adaptability; buildings; change factors; enablers; modelling; triggers

\section{Introduction}

\subsection{Adaptability of Buildings}

Building adaptability has been defined as "the capacity of a building to accommodate effectively the evolving demands of its context, thus maximizing value through life" [1]. The "accommodation" of "evolving demands ... " in buildings, which is inevitable over their lifecycle, involves the ability of the building fabric as it is to readily support the varied and changing needs of its users (i.e., the flexibility of a building), or to be easily modified/adapted to accommodate such changes when day-to-day adjustments are no longer feasible or desirable [2-5]. Both of these aspects, which reflect two broad dimensions of adaptability [6], involve early considerations for how spaces and different systems 
and components are designed, manufactured, and built to enable modifications to be made when required [7-10], and how adaptability can be retrofitted into existing buildings [5,11]. Adaptability can also be about how users and businesses change their lifestyles and operations in line with the configuration of buildings [12-15], a reality that is aptly captured in the quote from Winston Churchill (cited in [16], p. 3) that "we shape our buildings, and afterwards they shape us".

Adaptability, as a characteristic of buildings, is a key factor in managing the consequences of climate change, promote sustainability by prolonging the useful life of buildings and minimizing resource use, and as a practical solution to addressing the problem of building redundancy [5-7,17]. Adaptability or adaptive capacity is also linked to resilience (a key theme in the Sustainable Development Goals (SDGs) [18]); Circular Economy principles [19]; and the Open Building concept, a design approach that focuses on designing for change [20].

Previous research into the adaptability of buildings has sought to classify, conceptualize, model, and develop appropriate strategies for its implementation and assessment [2-9,21,22]. Theoretical models and conceptions of adaptability include the understanding that buildings are made up of layers with different rates of change: shell (structure, 50 years), services (e.g., heating, plumbing, 15 years), scenery (fittings, decorations, 5-7 years), and set (e.g., furniture, daily) [23]. This early categorization of layers was extended to six (site, structure, skin, services, space plan, and stuff) [16] and more recently to nine layers (surroundings, site, structure, skin, services, space plan, stuff, space, social) [24]. Other theoretical conceptions and models include the use of reliability theory and failure analysis to understand building performance and failure [5] and the development tools and methodologies to assess the adaptability of buildings [22,25].

Strategies for developing adaptable buildings which are underpinned by theoretical conceptions and principles have mainly focused on how the systems and components of the building fabric can be engineered to make them easy to change (e.g., making layers interdependent to facilitate change at a later date [24]). Some of these are focused on existing buildings or typology [26,27]. However, the trends in these have changed (and are changing) over time. The initial focus on the functional aspects of buildings (e.g., how to convert spaces) appears to be moving towards architectural tectonics, the integration of building systems, and more user-centered approaches $[6,14,24]$. However, change continues to be at the heart of building adaptability [17], both in terms of the nature of building use and the extent to which the building and its components can be modified to accommodate such changes.

\subsection{Change and Building Adaptability}

Changes in building use are the key drivers for adaptability. However, other external factors, such as changes in legislation (e.g., the need for disabled access to public buildings or fire safety regulations), environmental conditions due to climate change, and market forces (e.g., to respond to new business styles and ways of working) [5], can also necessitate a change in the building [6]. While change can be unpredictable [28], an understanding of how buildings learn and how they have changed over time [16,29] can provide insights into how to anticipate their adaptability [30].

Many studies on changes in buildings and construction have focused mostly on changes in project delivery [31-33]. Other studies have also looked at change in buildings in response to organizational change. For example, Leaman [34] proposed a conceptual framework for understanding change which considers the ability to make quick, short-term, and high-frequency changes (flexibility) and low-frequency changes in the long term (adaptability) against the constraints (e.g., low floor-to-ceiling heights) and congestion (e.g., sudden increased use of space) of building design and use (Figure 1). Thomson [35] outlines how buildings can respond to organizational change through facility planning. However, what is change? How can it be conceptualized with respect to building adaptability? 


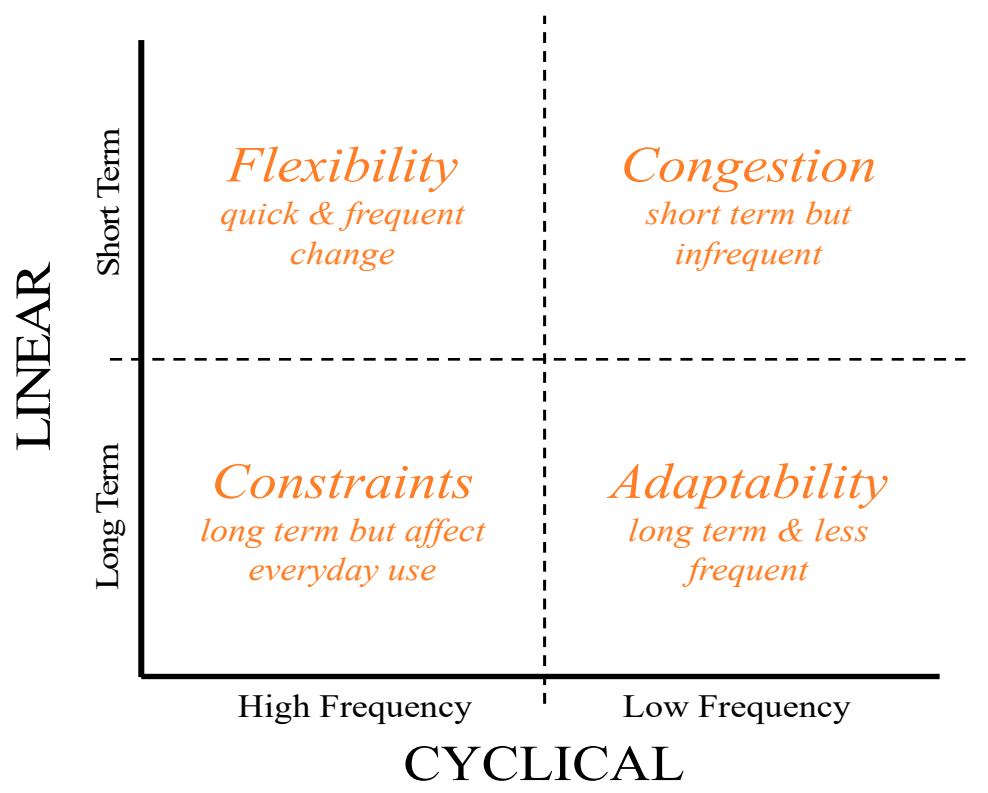

Figure 1. Framework for change (adapted from [34]).

Change can be understood in relation to time [36], and since buildings are dynamic objects, adaptability is very much about changes in time [37]. A formal definition by Worboys [38], p. 117, is that, "an object $\mathbf{o}$ changes if and only if there exists a property $\mathbf{P}$ of $\mathbf{o}$ and distinct times $\mathbf{t}$ and $\mathbf{t}^{\mathbf{1}}$ such that $\mathbf{o}$ has property $\mathbf{P}$ at $\mathbf{t}$ and $\mathbf{o}$ does not have property $\mathbf{P}$ at $\mathbf{t}^{1 "}$. Change is therefore with respect to the properties of an object, which could result from a change in its inherent attributes (e.g., modifying the characteristics of a building component) or a change in its relationship to other objects (e.g., change of ownership of a building). From a project delivery perspective, "change refers to an alteration to design, building work, project program or other project aspects caused by modifications to pre-existing conditions, assumptions or requirements" [31], p. 56. This suggests that change is with respect to a previously defined or agreed state or condition (e.g., change of contract conditions), and if applied to buildings can suggest a change from a defined state, function, or use (e.g., the completed building as it is, following the issue of a certificate of practical completion or final certificate [39]). These constructs of what change is (i.e., in inherent properties, against a defined base level, and in relation to other objects) will be considered in relation to adaptability through an exploration of the triggers for and types of changes that buildings undergo.

One perspective on the triggers for change which draws from reliability theory [30] is that change is a response to failure and is affected to correct deficiencies in building performance [5]. Failure in building performance in this context is not with respect to a building's overall fitness for purpose (i.e., its ability to provide shelter from the elements), but in the inability of the building to meet specific functional requirements (technical performance), lifestyle, consumer/user and market expectations (economic performance), and legislative requirements (legislative performance). However, while failure (i.e., less than optimum performance) can be in these three areas, the actual drivers for change arise when there is a difference between the user expectations and building performance (user fitness) or a difference between technical specifications and building performance (technical fitness), both of which are affected by external factors such as climate change, change in regulations, etc.) [5]. The resulting changes to address these deficiencies can range from decorating a space to a complete refurbishment (Table 1) [5,40-42], all of which can maximize the value of a building over its lifetime, as per the definition of adaptability above. However, it should be noted that these are changes to the building fabric and do not include the different ways a building as it is can support the varied and changing needs of users [6]. 
Occupant changes to adapt to the building fabric range from the day-to-day adjustments that individual users make (e.g., to opening/closing windows and blinds, putting on or taking off clothing, etc.) [43-45], to those that are in response to changes in organizational operations (e.g., changes to space layout) $[28,35]$. Day-to-day user adjustments stem mostly from the need to maintain a level of comfort (e.g., thermal and visual comfort), and are triggered by environmental (e.g., indoor and outdoor temperatures) and contextual factors which may be personal or organization-related [45]. Changes in organizational operations, which ultimately necessitate changes in buildings, arise from the need for enhanced business performance (e.g., efficiency, agility, profitability, etc.) [12,35]. These changes can be varied and triggered by both internal (e.g., staff changes) and external factors (e.g., change in legislation, civil unrest, change in market demand, etc.). While change can be planned, it is usually its unpredictability that poses more challenges in its management both from an organizational and building perspective [28].

The primary motivation for effecting change (whether planned or otherwise) is to improve or correct deficiencies (or failure) in a system [5,28]. However, change has implications and consequences. In the case of projects, changes can impact on their duration, cost, productivity, and allocation of risks [31,46]. For organizations, a change in operations might necessitate changes in buildings [35]. In buildings, changes to various components and systems can cause disruptions and impact on other components, people, and operations. An understanding of the nature, interrelationships, and implications of the multifaceted aspect of change in buildings is therefore key to building adaptability. Furthermore, the ability to predict such changes as has been done in predicting the likely duration of construction projects [46] will make a significant contribution to creating adaptable buildings.

Table 1. Types of changes to buildings (in alphabetical order).

\begin{tabular}{|c|c|}
\hline Type of Change & Meaning \\
\hline Adaptation & $\begin{array}{l}\text { "Any major works to adjust, reuse or upgrade a building to suit new } \\
\text { conditions or requirements" [5]. } \\
\text { "method of extending the useful life of buildings ... by a combination of } \\
\text { improvement and conversion" [41]. }\end{array}$ \\
\hline Decoration & $\begin{array}{l}\text { "... making something look more attractive by putting things on it or around } \\
\text { it ... " [47]. } \\
\text { "... covering [of] walls or other surfaces of rooms or buildings with paint or } \\
\text { paper" [47]. }\end{array}$ \\
\hline Improvement & $\begin{array}{l}\text { "combination of all technical, administrative and managerial actions, } \\
\text { intended to ameliorate the reliability and/or the maintainability and/or the } \\
\text { safety of an item, without changing the original function" [48]. }\end{array}$ \\
\hline & $\begin{array}{l}\text { Actions "... to retain an item or restore it to a state in which it can perform its } \\
\text { required function" [40]. }\end{array}$ \\
\hline Maintenance & $\begin{array}{l}\text { "combination of all technical, administrative and managerial actions during } \\
\text { the life cycle of an item intended to retain it in, or restore it to, a state in which } \\
\text { it can perform the required function" [48]. }\end{array}$ \\
\hline Modification & $\begin{array}{l}\text { "combination of all technical, administrative and managerial actions intended } \\
\text { to change one or more functions of an item" [48]. }\end{array}$ \\
\hline Rebuilding & $\begin{array}{l}\text { "action following the dismantling of an item and the repair or replacement of } \\
\text { those sub-items, that are approaching the end of their useful life and/or } \\
\text { should be regularly replaced" [48]. }\end{array}$ \\
\hline Refurbishment/Renovation & $\begin{array}{l}\text { "... modifications to meet current standards, but does not involve a change } \\
\text { of use" [41]. }\end{array}$ \\
\hline Rehabilitation & "recycling of buildings involving restoration and new construction" [41]. \\
\hline Repair & $\begin{array}{l}\text { "physical action taken to restore the required function of a faulty item" [48]. } \\
\text { "returns a building to the condition it was when originally constructed" [41] }\end{array}$ \\
\hline Restoration & $\begin{array}{l}\text { "event at which the ability to perform as required is re-established, after a } \\
\text { failure" [48]. }\end{array}$ \\
\hline Retrofitting & $\begin{array}{l}\text { "providing something [e.g., a building] with a component or feature [e.g., to } \\
\text { improve energy efficiency] not fitted ... when first constructed" [49]. }\end{array}$ \\
\hline
\end{tabular}




\subsection{Conceptual Model of Change and the Adaptability of Buildings}

The key findings from the review above are synthesized in Figure 2, which is a conceptual model of the interrelationships between change and building adaptability.

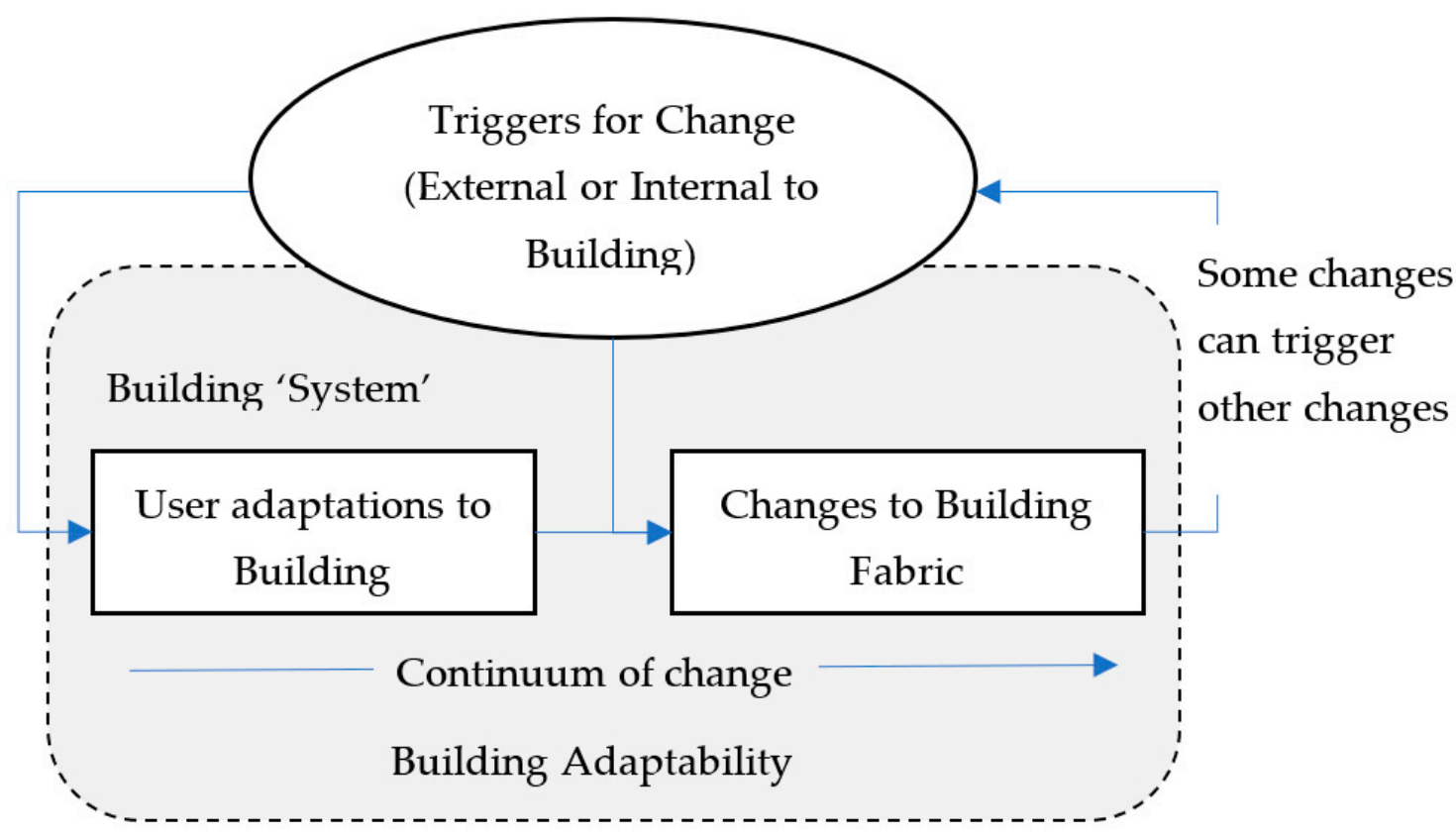

Figure 2. Conceptual model of change and building adaptability.

The building "system" represents the building fabric (i.e., the spaces, components, and systems within the building and immediate site), users, organization, and all actors or stakeholders that directly impact on the use and operation of the building. Building adaptability incorporates both user adaptations to the building as well as changes to the building fabric. The triggers for change represent various events (e.g., environmental, economic, financial) or actors (e.g., users, owners, external stakeholders), which can be external or internal to the building. Triggers can lead to changes by users to adapt to the building, or directly to changes to the building itself [18]. Similarly, user adaptations can get to the point where they are no longer adequate to provide a satisfactory level of comfort and/or performance, and changes to the building fabric become necessary. Changes to the building fabric (Table 1) relate only to changes in its attributes, and some of these can further trigger other changes. Changes to the relationship between the fabric and other objects such as a change in ownership will fall under the triggers for change to the fabric. The concepts and interrelationships represented in the model do, however, give rise to a few questions, which are the subject of the research presented in this paper. For example, what is the link between different triggers and the type and extent of change that is produced? The review by [45] shows that considerable research is being conducted on occupants' behaviors in buildings (within the category of "user adaptations"). However, at what point does this lead to building fabric changes? How can all these factors further enhance our understanding of building adaptability?

This paper reports research that conceptualized the process of change for enhancing our understanding of the adaptability of buildings. The previous and related work on change and change modelling reviewed above and the conceptual model (Figure 2) informed the empirical study, which is presented next. The paper concludes with recommendations on how the conceptual model can be further developed to enhance the development of more adaptable buildings of the future. 


\section{Research Methodology}

The objective of this research was to develop an understanding of the nature and categories of changes that buildings have to cope with and determine which elements of buildings are more susceptible to change-i.e., the triggers for and implications of such changes. Given the exploratory nature of the research, an interpretivist approach to discover knowledge from existing practices was adopted [50]. With the added intention of developing a model of change, it also reflects a form of Grounded Theory research [51], although there is some framing of the study by the conceptual model in Figure 2. Interpretivist research usually lends itself to the use of qualitative methods, and a case study approach was therefore adopted, as it is more appropriate for dealing with exploratory research $[52,53]$.

The changes in two buildings in the north east of England, UK (Figure 3), were studied to provide empirical evidence for this study. Building 1 is a commercial building and business incubator center on five levels (basement $(-1)$, street level $(0), 1,2,3)$. It was built in 2009 by a developer who was encouraged to regenerate an area earmarked for development by the local government authority. It was part of the first phase of (three) buildings that were part of the master plan for the area, designed to promote small-business development and employment generation. Building 2 is a Grade 1 listed 13th century AD church currently deconsecrated and hosting a heritage center, a book shop, and other activities. Both buildings are owned by a local government authority, who were the industrial partners to the research reported in this paper. The buildings were selected mainly because of ease of access to documents and to some of the key stakeholders involved in their creation, adaptation, and management.

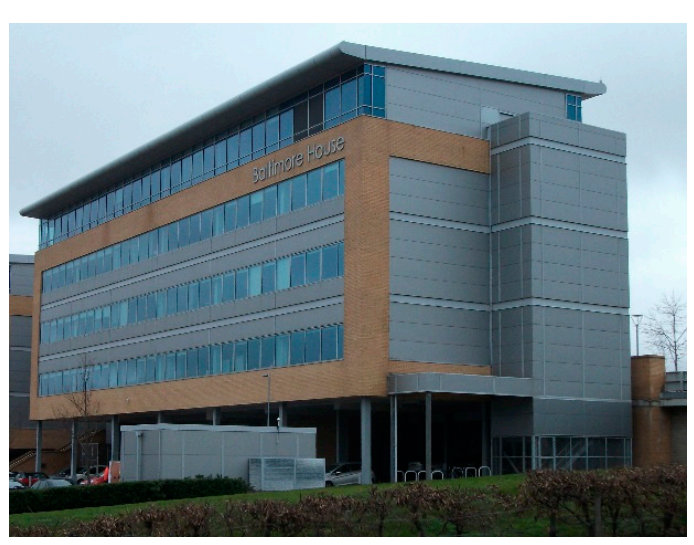

Building 1

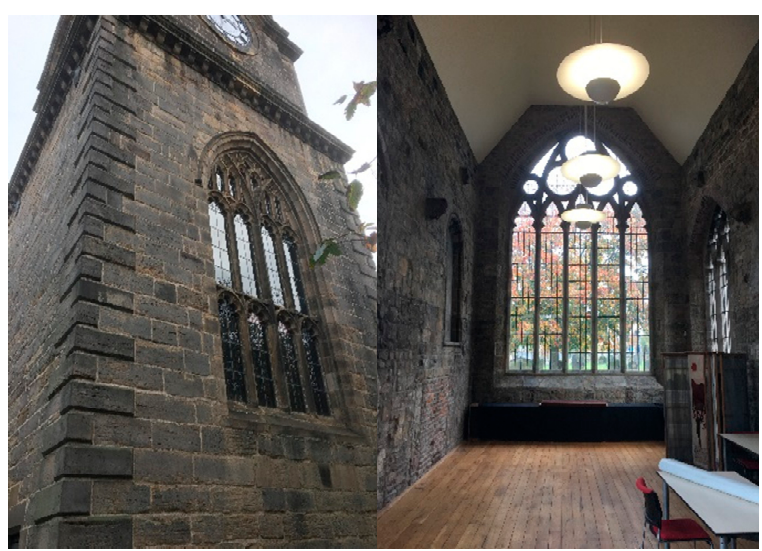

Building 2

Figure 3. Images of Buildings 1 and 2 (source: field survey of buildings).

Data collection was carried out between March and December 2016, and involved the examination of project documents (e.g., drawings and specifications, tender documents/contractor proposals); semi-structured interviews with key stakeholders, most of which were recorded, transcribed, and validated by the interviewees; and physical/visual surveys of the buildings. The details of specific data sources for each building are summarized in Table 2. All the interviews for Building 1 and interview 2 for Building 2 were recorded with the permission of the interviewees. Interview 1 for Building 2 was conducted whilst on a visual survey/walk around the building and was therefore not possible to record; however, notes of key points were made. All the recordings were transcribed and validated by interviewees as a correct record of what was discussed.

All the interviews were based on a template that included a brief description of the research project, the objectives of the interview, an outline of topics to cover during the interview, and assurances about how the data was going to be used. The topic areas, which were slightly modified to suit each interviewee, included the role/background of the interviewee, background to the building, general management, changes made to the building (e.g., type, process, triggers for, and effects of change, etc.), 
and any other relevant issue. Each interviewee was sent the interview template at least $24 \mathrm{~h}$ before the interview.

Data analysis was performed using the NVIVO software for qualitative analysis. This software is designed to help organize, analyze, and find insights into un-structured or qualitative data such as interviews. All the project-related documents (i.e., drawings, interview transcripts, photographs, and other project documents) were uploaded to NVIVO. A list of themes (called "nodes" in Nvivo) around key research questions (e.g., the reasons behind the changes, the types of changes, and the flexibility of changes) were created. These nodes were then linked (coded) to the interviews to facilitate the data analysis during the research. Some manual analysis was also carried out, for example in establishing the timeline of changes, and in the review of building documents.

Table 2. Summary of data sources.

\begin{tabular}{|c|c|c|}
\hline Source & Building 1 & Building 2 \\
\hline Documents & $\begin{array}{l}\text { 1. Original and updated drawings of building. } \\
\text { 2. Contractor's proposals for refurbishment. } \\
\text { 3. Market research report for purchase of } \\
\text { the building. }\end{array}$ & $\begin{array}{l}\text { 1. Publication about the history } \\
\text { of the building. } \\
\text { 2. Conservation plan. } \\
\text { 3. Drawings for major works } \\
\text { completed in } 2008 \text {. }\end{array}$ \\
\hline & Five interviews: & Two interviews: \\
\hline Interviews & $\begin{array}{l}\text { 1. Original Architect for building (OA). } \\
\text { 2. } \text { Building Manager (BM). } \\
\text { 3. Architect for Major Refurbishment (AM). } \\
\text { 4. Business development manager (Building } \\
\text { 5. } \\
\text { Client) (BC). }\end{array}$ & $\begin{array}{l}\text { 1. Architect for the major } \\
\text { refurbishment completed in } \\
2008(\mathrm{AR}) \text {. } \\
\text { 2. Creativity Development } \\
\text { Manager for building } \\
\text { (CDMgr). }\end{array}$ \\
\hline Other & Visual on-site survey of building. & Visual on-site survey of building. \\
\hline
\end{tabular}

\section{Research Findings}

\subsection{Building 1}

Table 3 summarizes the key events and changes in the building at the time of the study. The development and construction of the building coincided with the start of the recession in the UK (2007/2008), and the building was unoccupied for three years (2009-2012). In 2012-2013, the top floor (level 3) was partitioned into cellular offices and this attracted tenants. However, full occupancy was not achieved until after major refurbishments were carried out (mainly the partitioning of levels 1 and 2), following the acquisition of the building by the Local Authority in 2014. Figure 4 shows the network of departments and individuals that were involved in the decision-making for change to happen. The case for the purchase of the building was made by the Economic and Housing Growth department (the key driver behind these decisions), but the actual acquisition was carried out by the Legal, Democratic, and Property Services.

The building had been designed as fully open plan (Figure 5) based on a business model of attracting "a blue chip big corporate [tenant] to come in and rent [or buy] the whole building ..." (Interviewee BC-Table 2). However, given the adverse economic conditions at the time, this did not happen. This was of grave concern to the Local Authority, who wanted to promote economic development in the area. They were concerned that an empty building was not a good advert for the area and was unlikely to encourage further investment in office buildings. The developer was then persuaded to partition the top floor (level 3) by the Local Authority, who had a waiting list of small businesses wanting more space to which they could expand and create employment in the area 
(Interview BC). Following the success in attracting tenants for the partitioned floor, the authority hoped that the developer would go on to partition the rest of the building, but they were not interested in becoming a landlord to multiple tenants, preferring one point of contact for managing the building. This led to the acquisition of the building by the Local Authority, who at the time were looking for more space to house small technology-based incubator businesses.

Table 3. Timeline of key events and changes in Building 1.

\begin{tabular}{|c|c|c|}
\hline Date(s) & Details & Ownership \\
\hline $\begin{array}{c}2009 \\
2009-2012 \\
2012-2013\end{array}$ & $\begin{array}{l}\text { Building built. } \\
\text { Building un-occupied. } \\
\text { Level } 3 \text { (middle floor) partitioned into } 8 \text { units. } \\
\text { Major refurbishment comprising of: }\end{array}$ & Developer \\
\hline 2014 & $\begin{array}{l}\text { - } \quad \text { Partitioning of levels } 1 \text { and 2; } \\
\text { - Improvements to mechanical and electrical services (lighting, security, } \\
\text { electrics, etc.); } \\
\text { - } \quad \text { Improvements to external escape stairs; } \\
\text { - } \quad \text { Installation of soft flooring and general decoration. }\end{array}$ & Local Authority \\
\hline 2016 & Soundproofing works on new partitions increased broadband connections. & \\
\hline
\end{tabular}

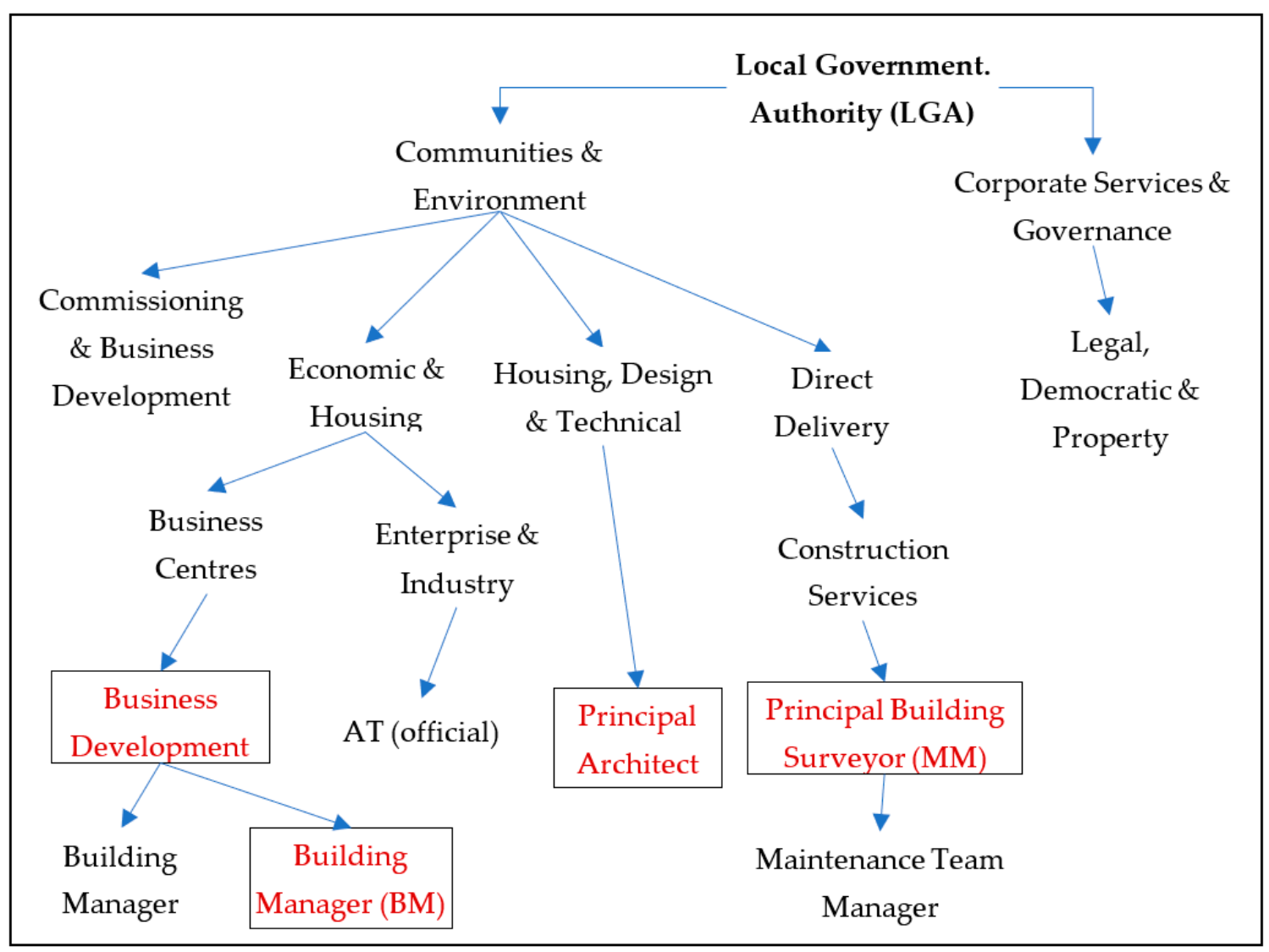

Figure 4. Stakeholders involved in decision-making for changes to Building 1 (boxed roles are interviewees for this research-see Table 2). 
This change in ownership and business model underpinning the use of the building led to the major changes summarized in Table 3: i.e., the partitioning of levels 1 and 2, and improvements to mechanical and electrical services, external escape stairs, etc. The main purpose was "to enhance the scope of the building to bring several SME's [small and medium-sized enterprises] together under one roof" (contractor's proposal for refurbishment-Table 2). This work was carried out by an external contracting company, which outsourced the design aspect to the trading arm of the Local Authority (under which the architect for the refurbishment-AM in Table 2-operated). In addition, the Local Authority also appointed a resident building manager (BM in Table 2) to take care of the day-to-day activities. However, either because of the need for speed (planned construction program was 15 weeks and 4 days) or to minimize costs (contract value was about $£ 1.3 \mathrm{~m}$ ), the partition walls only went up to ceiling height (Figure 6), and this resulted in serious problems with sound transmission between offices (occupied by different companies, including potential competitors). This problem led to further improvements in 2016 to improve the soundproofing at a cost of about $£ 35 \mathrm{k}$. (thirty-five thousand pounds sterling).

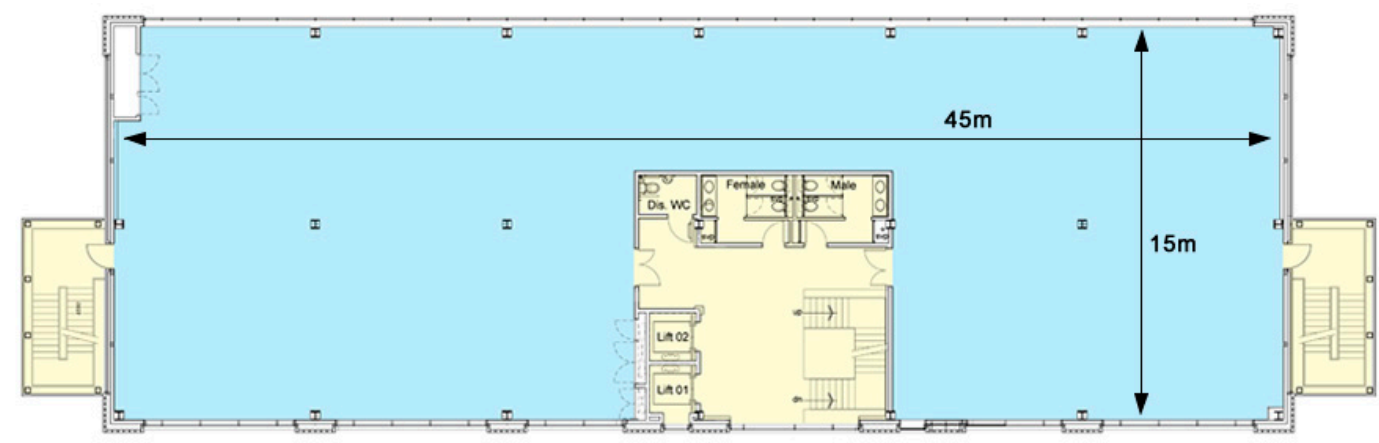

SECOND FLOOR PLAN

Figure 5. Original typical floor plan of Building 1.

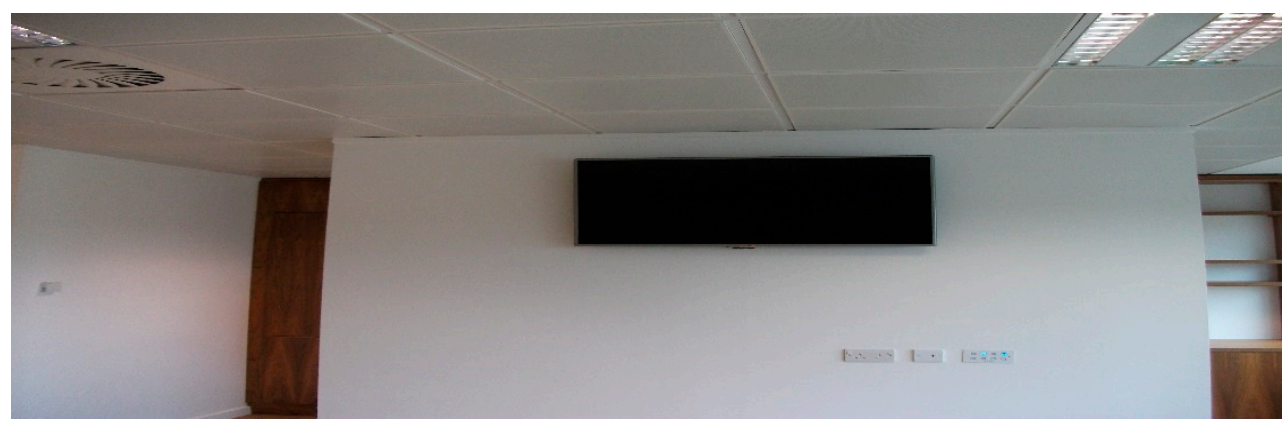

Figure 6. Image of partition walls of building 1 (source: field survey of building).

\subsection{Building 2}

The timeline of changes to the building that was pieced together from various documents (Table 2) is summarized in Table 4, although the focus of the research was mainly the changes made since the current owners acquired the building in 2003. According to the architect (AR-Table 2) for the major refurbishment which was completed in 2008 , the changes made at the time included a new wooden floor over the existing concrete floor (Figure 7); the relocation of services under the floor (heating and electrical ducting); a new removable and reversible extension to provide a better location for the toilets (previously housed inside the north-east side of the main aisle) and boiler; the installation of new bespoke structural single glazing windows, a wireless fire alarm, and IT services in the crypt of the building underneath the tower (Figure 8). No major changes were made to the fabric of the building, since it is a listed building. 
The completion of the major works in 2008 was followed by the economic recession, which affected many western nations from 2008. These adverse economic conditions forced the owners to withdraw operational support for the heritage center, requiring a change in the business model in terms of its operations to include activities (e.g., hiring the venue as an events space for meetings, conferences, and weddings) that will make it self-supporting (CDMgr and AR-Table 2).

Table 4. Timeline of the key events and changes in Building 2.

\begin{tabular}{|c|c|}
\hline Date & Details of Changes \\
\hline $11-14$ century AD & $\begin{array}{l}\text { Anglo-Saxon wooden church destroyed in 1080. A small chamber was built in } 1350 \text { on } \\
\text { the north-east side. However, some elements of the church have been dated from } \\
\text { around } 1200 \text { AD. }\end{array}$ \\
\hline 16 century & The chamber was enlarged for hosting the Four and Twenty meetings. \\
\hline 1644 & The church is occupied by Scots and bombarded by Newcastle royalists. \\
\hline 1693 & School in the anchorage. \\
\hline $1739-40$ & Tower rebuilt and major repairs to building. \\
\hline $1838-40 \mathrm{~s}$ & $\begin{array}{l}\text { Repairs and extensive alterations to building, including the installation of hot water } \\
\text { heating in the church. }\end{array}$ \\
\hline 1854 & Great fire of Newcastle and Gateshead. \\
\hline $1854-55$ & Restoration by John Dobson (a local architect). \\
\hline $1874-75$ & Repairs and alterations by Austin, Johnson, and Hicks. \\
\hline $1908-22$ & Repairs and alterations by Oliver Leeson and Wood, improvements to the graveyard. \\
\hline 1922 & West window replaced by stained glass by Charles Kempe. \\
\hline 1925 & Tyne Bridge Act: purchase of sections of graveyard to build bridge. \\
\hline 1932 & Graveyard alterations and removal/relocation of c200 tombstones. \\
\hline 1950 & $\begin{array}{l}\text { Added to ("Listed" in) the National Heritage List for England as a building of } \\
\text { exceptional architectural or historic interest (Grade } 1 \text { listed building). }\end{array}$ \\
\hline 1979 & Fires in vestry and tower. The church ceased to be a place of worship. \\
\hline 1984 & Proposed repair works to boundary walls, railings, and piers. \\
\hline 1985 & The church is acquired by the North East Civic Trust. \\
\hline 1990 & Auction house: refurbishment and use by Philips Fine Art Auctioneers. \\
\hline 2001 & Converted into a visitor center. \\
\hline 2003 & Purchase by the current owners, following a four-year lease. \\
\hline 2007 & New design proposal for the conversion into a heritage center. \\
\hline 2008 & Works completed. \\
\hline 2008-2016 & $\begin{array}{l}\text { In-use changes after the works' completion: freestanding boxes for additional plugs, } \\
\text { additional heating system, window blinds. }\end{array}$ \\
\hline
\end{tabular}

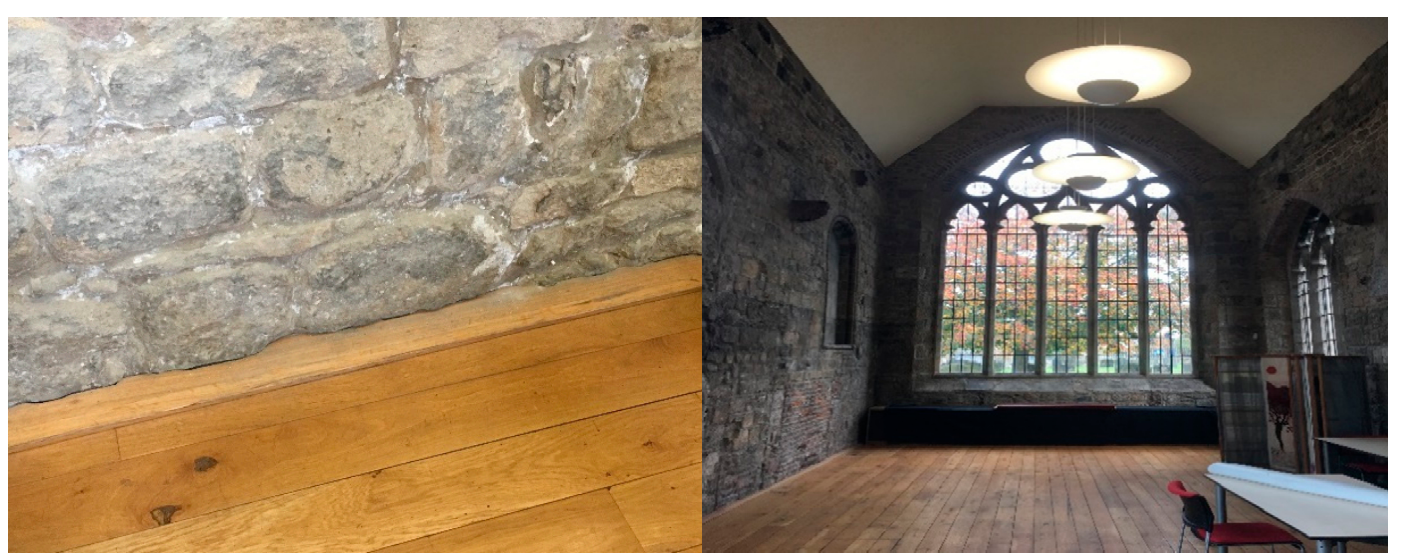

Figure 7. Finished floor of Building 2 (source: field survey of building). 


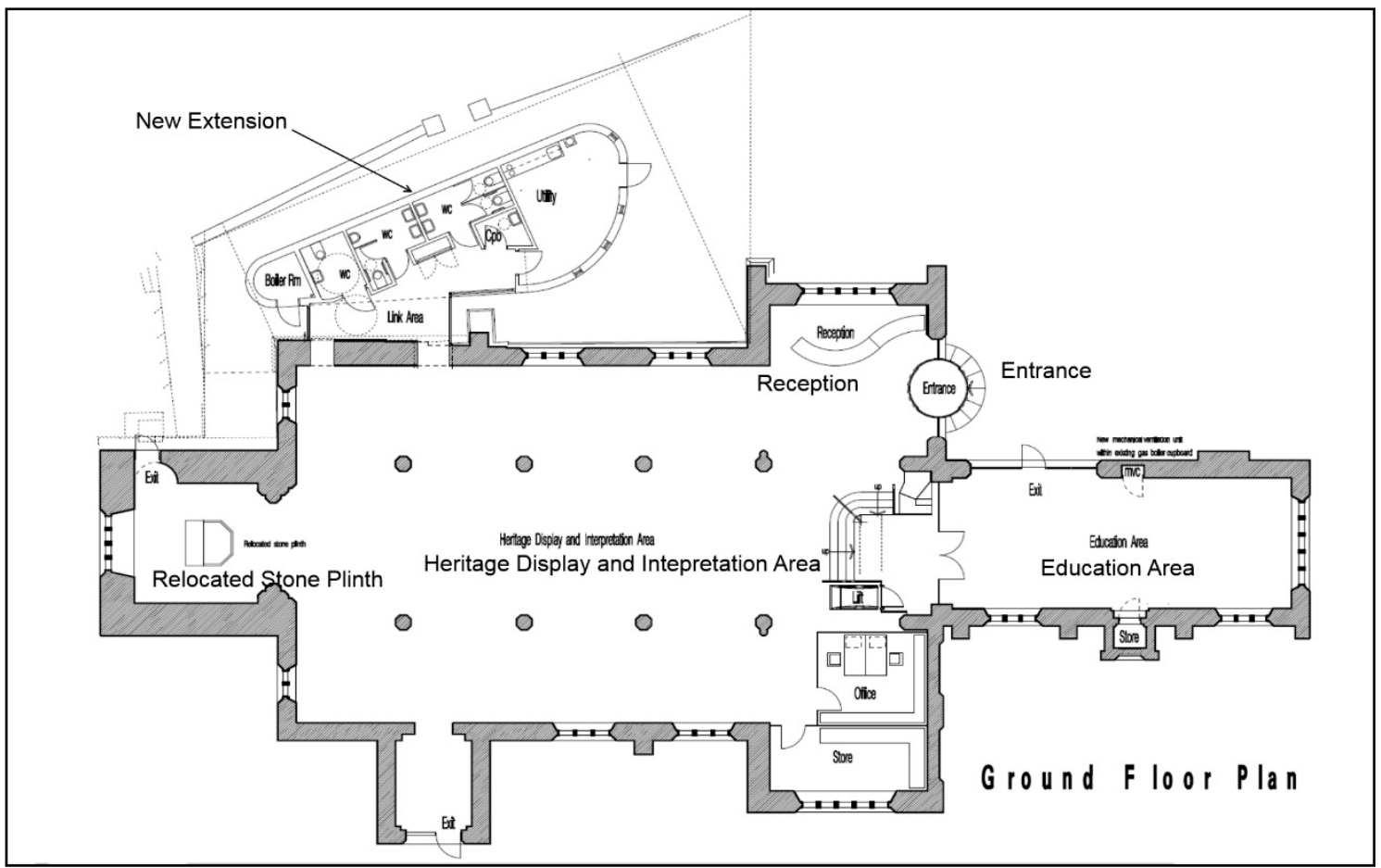

Figure 8. Ground floor plan of Building 2 (source: drawings of major works-Table 2).

The modified change in operations necessitated further changes to the building, including the addition of bespoke boxes for cables to provide extra electric sockets along the main aisle (the underfloor boxes were too small for some plugs and a number of devices could not be used) (Figure 9); the installation of additional heating, comprising radiators, fans, heaters, and blinds on windows to the south to provide shading for activities in that part of the building. However, despite these additional improvements, there were (at the time of the interview) ongoing challenges to do with storage (especially for the chairs used for various events); limitations of the electrical system to cope with activities not envisaged at the time of the major refurbishment in 2008; and managing the delicate balance between income generation and preserving the building as a listed building.
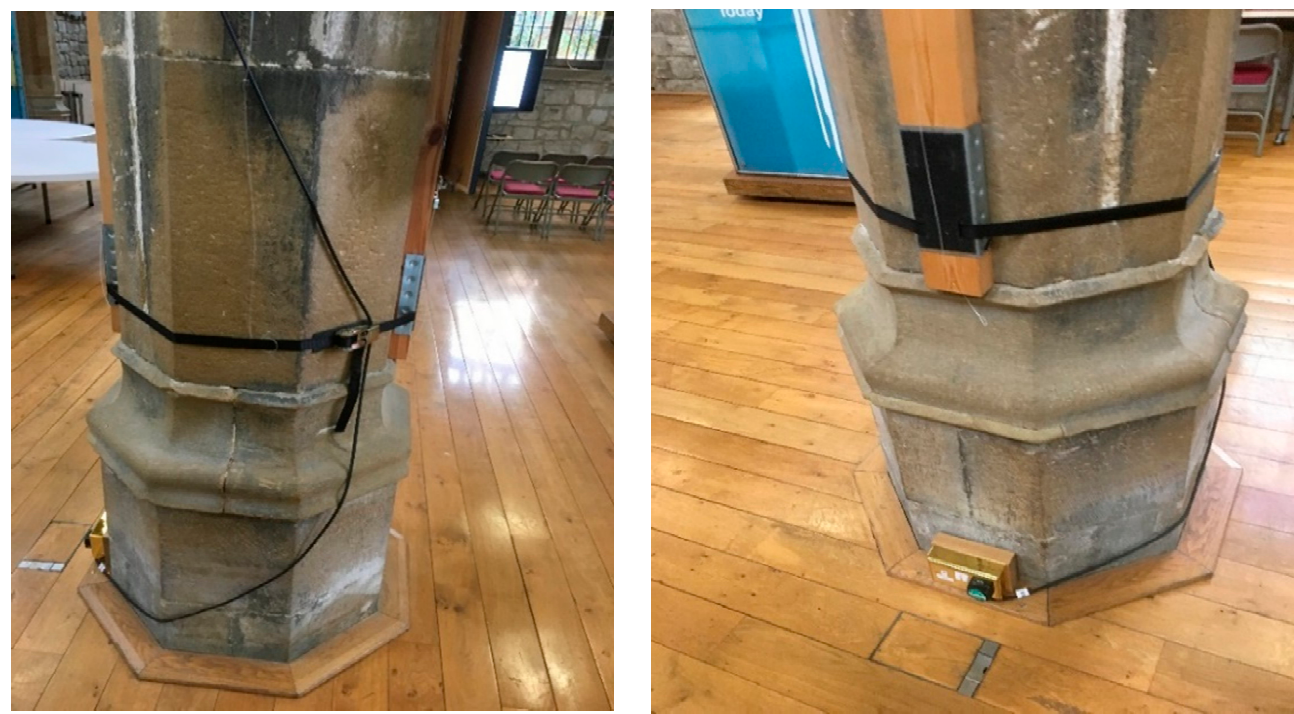

Figure 9. Further changes to Building 2 to provide more usable electric sockets. 


\section{Discussion}

A key question underpinning this research was: how can an understanding of change further enhance our ability to create more adaptable buildings? The conceptual model of building change (Figure 2) provides the framework for analyzing the findings from the research with respect to the triggers for change and the actual changes made to the building fabric. Although user adaptations were not specifically investigated, the other findings will be used to make inferences on their nature and implications for adaptability.

\subsection{Changes to Buildings}

From the description of the two buildings above, the building layers $[16,18,24]$ that changed were: stuff, space plan, and services (Building 1); stuff, space plan, services, structure, skin, and site (Building 2) (Table 5). New developments in the "surroundings" of both buildings might have triggered or influenced the changes made within them. On the other hand, the changes made to the building fabric of both buildings affected the "social" layer because of the different groups of building users. The type of changes made spanned most of the types described in Table 1, although there was no change in use, except for Building 2, whose use had been changed from a place of worship to a heritage center. However, these changes only reflect major works on these buildings; many other changes such as statutory maintenance to comply with legislation were made. The as-built drawings of these buildings may or may not be updated after such changes (interviewee MM-Table 2).

Table 5. Changes in study buildings mapped against Schmidt III and Austin's [24] building layers.

\begin{tabular}{|c|c|c|c|}
\hline Layer & Description & Building 1 & Building 2 \\
\hline Social & $\begin{array}{l}\text { "Humans in and around the } \\
\text { building that play a role in the } \\
\text { life of the building". }\end{array}$ & $\begin{array}{l}\text { A mix of small start-up } \\
\text { businesses occupied the } \\
\text { building. }\end{array}$ & $\begin{array}{l}\text { Regular (staff) and } \\
\text { occasional users (visitors } \\
\text { and events participants) } \\
\text { now occupy the } \\
\text { building. }\end{array}$ \\
\hline Stuff & $\begin{array}{l}\text { "components/objects that } \\
\text { reside inside the space users } \\
\text { inhabit", }\end{array}$ & $\begin{array}{l}\text { New fixtures and } \\
\text { furniture installed. }\end{array}$ & $\begin{array}{l}\text { Window blinds and } \\
\text { furniture installed. }\end{array}$ \\
\hline Space Plan & $\begin{array}{l}\text { "components that enclose the } \\
\text { spaces users inhabit". }\end{array}$ & $\begin{array}{l}\text { Partitions put in and } \\
\text { decoration. }\end{array}$ & $\begin{array}{l}\text { Some partitions added. } \\
\text { Improvements made to } \\
\text { the space. }\end{array}$ \\
\hline Services & $\begin{array}{l}\text { "components that supply and } \\
\text { transport physical } \\
\text { flows-energy, water, } \\
\text { communications, elevators". } \\
\text { "components which support }\end{array}$ & $\begin{array}{l}\text { Some improvements } \\
\text { made to facilitate other } \\
\text { changes (e.g., partitions). }\end{array}$ & $\begin{array}{l}\text { New improved services } \\
\text { put in (e.g., underfloor } \\
\text { heating in new } \\
\text { extension). }\end{array}$ \\
\hline Structure & $\begin{array}{l}\text { the primary transferring of } \\
\text { vertical loads and horizontal } \\
\text { bracing". }\end{array}$ & Not changed. & $\begin{array}{l}\text { Repairs were made to the } \\
\text { structure. }\end{array}$ \\
\hline Skin & $\begin{array}{l}\text { Exterior surfaces (e.g., façade, } \\
\text { cladding). }\end{array}$ & Not changed. & $\begin{array}{l}\text { Improvements } \\
\text { (repointing) made to } \\
\text { brickwork. }\end{array}$ \\
\hline Site & $\begin{array}{l}\text { "the legal boundary in which } \\
\text { the building sits". }\end{array}$ & Not changed. & $\begin{array}{l}\text { An extension was built } \\
\text { to house the toilets. }\end{array}$ \\
\hline Surroundings & $\begin{array}{l}\text { "The larger physical context in } \\
\text { which a building sits, outside } \\
\text { of its specific lot boundaries" } \\
\text { (includes human-made objects } \\
\text { and natural geographic } \\
\text { conditions). }\end{array}$ & $\begin{array}{l}\text { A further education } \\
\text { college had been built in } \\
\text { an adjacent site as part of } \\
\text { the regeneration of the } \\
\text { surrounding area. }\end{array}$ & $\begin{array}{l}\text { A music and concert } \\
\text { venue had been built } \\
\text { near this building prior } \\
\text { to its main refurbishment } \\
\text { in } 2008 \text {. }\end{array}$ \\
\hline
\end{tabular}


It is observed that, whilst the changes in the buildings studied can be mapped against defined building layers, the actual changes to those elements were not made because they had reached the expected lifespan of when changes to different building layers could be expected (e.g., major changes were made to building, which was relatively new and had barely been occupied). The changes made and the sequence in which they were made were not dependent on the expected lifespans, but on the need for strategic objectives and the need for a well-functioning building in line with those objectives. Other changes were triggered because of key changes (e.g., the need for partitions in the building led to the need to change the services). However, this does not undermine the need for layer independence in building design as an adaptability strategy [16], and although this was not investigated in this study, it may well have enhanced the cost-effectiveness of the changes made to the building [18].

\subsection{Triggers and Enablers for Change}

For both buildings (1 and 2), there were several triggers for making changes to the buildings (Table 6), which fall into three categories:

- Indirect, macro-level (e.g., economic downturn) vs. direct, micro-level (e.g., change in ownership) triggers.

- Building use (i.e., initiated out of the day-to-day use of the building) vs. non-building use (e.g., top-down strategic change in the business) triggers.

- Building-change triggers which arise from the changes triggered by the above.

Figure 10 shows the relationships between the triggers. Some of the triggers were interrelated, with some (e.g., micro-level triggers) arose from others (e.g., macro-level triggers). Most of the triggers also led directly to changes in the building fabric (as suggested in the conceptual model in Figure 2), although a few (e.g., changes arising from change in operations in Building 2) were building use-related. For both buildings, the triggers that actually led to building change also appear to be directly linked to strategic business decisions, which were made not because of a bottom-up assessment of use, but because of external "top-down" macro-level factors (Figure 10).

Table 6. Triggers for change in the case study buildings.

\begin{tabular}{|c|c|c|c|}
\hline Category & Triggers & Building 1 & Building 2 \\
\hline Macro/Non-Use & Economic conditions. & $\begin{array}{l}\text { Affected initial occupancy and } \\
\text { eventually led to a change in } \\
\text { ownership and changes within } \\
\text { the building. }\end{array}$ & $\begin{array}{l}\text { This led to the } \\
\text { withdrawal of funding, a } \\
\text { change in the business } \\
\text { model, and then to } \\
\text { building changes. }\end{array}$ \\
\hline Micro/Non-Use & Disasters. & $\begin{array}{l}\text { Bankruptcy of original owners. } \\
\text { Led to change in the business }\end{array}$ & Damage caused by fire. \\
\hline Micro/Non-Use & Change in ownership. & $\begin{array}{l}\text { model and then to building } \\
\text { changes. }\end{array}$ & Led to building changes. \\
\hline Micro/Non-Use & $\begin{array}{l}\text { Change in business } \\
\text { model. }\end{array}$ & $\begin{array}{l}\text { From single occupancy to } \\
\text { multiple occupancy. }\end{array}$ & $\begin{array}{l}\text { From grant funding from } \\
\text { owner to increased } \\
\text { income generation. }\end{array}$ \\
\hline Micro/Non-Use & $\begin{array}{l}\text { Need to increase } \\
\text { revenues. }\end{array}$ & $\begin{array}{l}\text { Need to attract more business to } \\
\text { the area and thereby increase the } \\
\text { revenues of the Local } \\
\text { Government Authority (LGA) } \\
\text { through business rates. }\end{array}$ & $\begin{array}{l}\text { Need to generate } \\
\text { revenues to make it } \\
\text { self-supporting. }\end{array}$ \\
\hline Micro/Building-Use & $\begin{array}{l}\text { Changing needs of } \\
\text { users. }\end{array}$ & $\begin{array}{l}\text { Noise/sound-transmission } \\
\text { issues between the spaces of } \\
\text { different tenants. }\end{array}$ & $\begin{array}{l}\text { Need to cater for } \\
\text { different activities. }\end{array}$ \\
\hline Micro & Building changes. & $\begin{array}{l}\text { Decoration works that were part } \\
\text { of the major refurbishment } \\
\text { (partitioning of spaces). }\end{array}$ & $\begin{array}{l}\text { Remedial decoration as a } \\
\text { result of other changes. }\end{array}$ \\
\hline
\end{tabular}




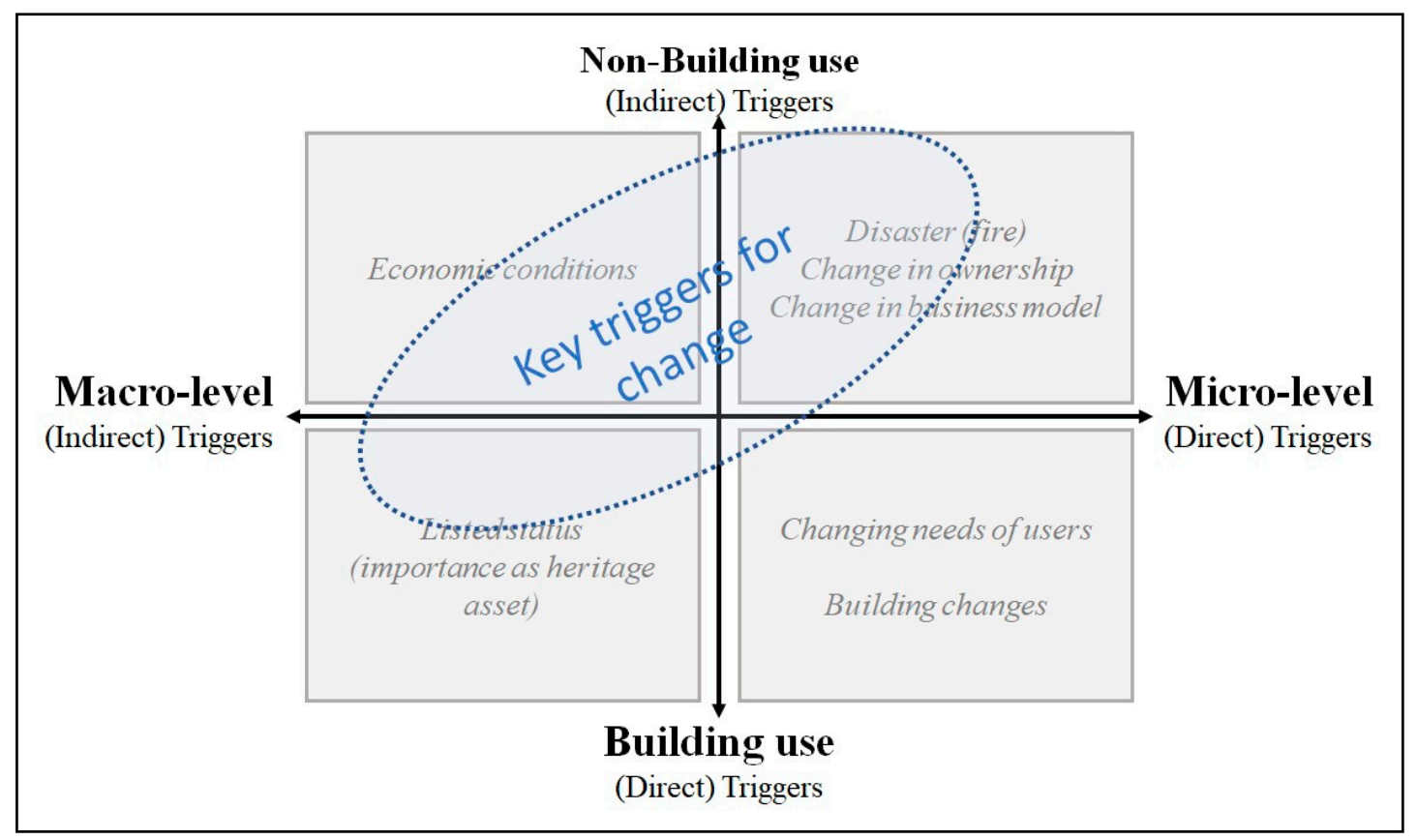

Figure 10. Relationships between triggers for change in case study buildings.

Closely related to the triggers for change are the enablers or inhibitors for making the change. For both buildings, these were: organizational will, regulations, the cost of change (against the perceived benefits), and funds. Organizational will relates to the motivation desire of the building owner/organization to make change. This was especially the case in Building 1, where there was concerted effort by the Local Government Authority (LGA) to make sure the building was partitioned so that it could attract tenants. This was obviously motivated by the need to encourage the economic development and regeneration of the area, and to generate income through business rates (interviewee BC-Table 2). Regulation was also another enabler, especially for Building 2, as the listed (protected heritage) status facilitated the grant from the Heritage Lottery Fund to be secured. However, it was also an inhibitor, as there were severe restrictions on the changes that can be made on the fabric of the building leading to significant expense in maintaining the wall profile (no skirting boards were permitted-Figure 7), and in embedding service cabling within the mortar joints. Another key enabler was the cost of change and access to funding to effect changes. For both buildings, funding was received from the European Union, and also from the UK Heritage Lottery Fund in the case of Building 2 , to acquire and/or refurbish them. Regarding the role money plays in effecting change, interviewee MM (Table 2) observed that: “ . . you can make anything adaptable. It's all to do with money, isn't it? You can do whatever you want as long as you have got the money", although he did acknowledge that building configurations that are easy to change will make this easier.

The cost of change was obviously linked to the ease of changing the building factors, but it appeared that organizational will (as in Building 1) played a greater role as an enabler for change. It does seem that organizational will and money can override less flexible building conditions. Interviewee BC (Table 2) observed that, from his experience, “ . . it's easier [more cost effective] to take walls away than add them in [i.e., partition larger spaces]; it's more difficult to design larger spaces and turn them into smaller spaces". However, although this was the challenge for Building 1, the changes were made nonetheless, because they were considered crucial for the reasons mentioned earlier. 


\section{Conclusions}

The aim of the research reported in this paper was to conceptualize and explore the process of change to enhance our understanding of the adaptability of buildings. Through an exploratory study, the changes in two buildings were investigated and the findings were discussed against the conceptual model that was presented in this paper.

A definition of adaptability that focused on a building's ability to accommodate the changing demands of its context to maximize its value over its lifetime [1] was adopted for this study. This underscores the fact that change is at the heart of building adaptability, but that it incorporates both the extent to which users adapt to buildings as well as the changes made to the building fabric to accommodate the changing contexts of the building. The concept of change was therefore explored, and it was established that it relates both to the changes in the inherent attributes of an object and the changes in the relationship to other objects. In the context of buildings, this translates to a wide spectrum of changes (Table 1) to the building fabric (inherent properties) and changes in ownership, users, and external entities interacting with the building (relationship to other objects). Since the focus of the study was on "change" rather than on the building's ability to respond to that change, the triggers and enablers that lead to changes to buildings were investigated. The likely interrelationships between these factors are represented in the conceptual model (Figure 2) that informs that empirical study reported in this paper.

\subsection{Limitations of the Study}

One of the key limitations in this study is that "user adaptations to buildings" was not investigated due to the lack of data; the full extent of the conceptual model could not therefore be explored. However, even for those aspects investigated, it was not possible to map all the changes within the buildings studied, apart from those which took place during major refurbishments. Even though key participants were interviewed, the lack of routine capture of all the multitude of changes made it impossible to have this information. Finally, because of the exploratory nature of the study and the focus on only two buildings, the findings only apply to these buildings, and cannot be statistically applied to all buildings.

\subsection{Conclusions and Implications for Practice and Research}

The limitations of the study notwithstanding, many valuable insights were drawn from the study, and these are summarized below:

1. "The concept of building layers is useful for categorizing changes, but not necessarily in predicting when changes will be made." It was observed that while the changes that were made to the studied buildings were categorized into defined building layers (e.g., space, services, structure-Table 5), the changes were not necessarily triggered because various elements were obsolete (as implied by the lifespans of different layers), but rather to respond to changing business and external factors. A possible implication of this is that a new way of predicting and/or categorizing building changes needs to be developed, as the actual changes made may not necessarily follow the lifespan model of layers. Furthermore, given the wide spectrum of changes within layers (e.g., the services layer), sub-layers could be considered to predict and/or develop more appropriate and targeted adaptability strategies.

2. "The apparent 'state' of being 'adaptable' did not appear to be relevant with respect to the changes made to the studied building." The findings from this research suggests that the state of being adaptable does not necessarily mean that actual change to the building will be made if other factors are not favorable. On the other hand, when these other non-building-related factors are strong enough, actual change can be made even if the building fabric itself is not very adaptable. An implication of this is that more consideration needs to be given to non-building factors in adaptability studies. For example, could these be a better indicator of the likely 
changes to buildings than building layers? Could they provide better insights into the design for adaptability?

3. "Building 'failure' with respect to meeting strategic business objectives and regulation were most crucial in triggering the changes to buildings." Non-building use triggers were more crucial in bringing about change (Figure 10), and building-use issues (e.g., sound insulation in Building 1) only became relevant because they had a direct effect on those strategic issues. For both buildings, the need to fully comply with regulations (e.g., the listed status of Building 2) necessitate ongoing changes, many of which are not routinely documented. However, since the "user adaptations to building" aspect of the conceptual model (Figure 2) was not investigated, the extent to which "failure" in this area led to building changes was not explored. This conclusion should therefore be considered as preliminary, and further research is required to fully explore the way different types of building failure affect the changes produced.

4. "The triggers for change are themselves susceptible to change." The original business models for both buildings had envisaged a type of use which influenced the design/refurbishment. In Building 1, the open plan nature of the building reflects accepted wisdom on adaptability [2], but the services were not designed to enable spaces to be easily partitioned. The new business model was based on multiple occupancy for small start-up companies requiring smaller offices. In Building 2, the change to a self-sufficient income-generating building led to further changes to accommodate a different type of use. A possible implication of this is that if potential changes in demand were envisaged at the time of design/refurbishment, could this have led to more adaptable solutions? The anecdotal evidence from this research suggest that this may not be the case; the sound transmission problem in Building 1 was envisaged when it was refurbished but was not initially implemented because of budget and time constraints.

In conclusion, it is evident that the conceptual model provides a useful framework for investigating and developing an understanding of change and the adaptability of buildings. The insights reported in this paper suggest that a greater understanding of how non-building factors lead to changes in buildings will greatly enhance our ability to create more adaptable buildings. Further research in the areas highlighted above and on a wider sample of buildings is required to ensure the wider application of the findings by researchers and practitioners in the built environment and allied disciplines.

Author Contributions: Conceptualization, J.M.K.; methodology, J.M.K., O.H., V.E.T.; formal analysis, J.M.K. and V.E.T.; investigation, J.M.K. and V.E.T.; data curation, J.M.K., V.E.T.; writing-original draft preparation, J.M.K.; writing-review and editing, O.H., S.M., M.C.D., F.R.C.; funding acquisition, J.M.K., O.H. All authors have read and agreed to the published version of the manuscript.

Funding: This research was funded by Newcastle University Institute for Sustainability, Newcastle upon Tyne, UK, project number BH153225.

Acknowledgments: We acknowledge with thanks the support of the industrial collaborator to this project for access to the project and building information, and the time and input of all their staff who were interviewed as part of the research.

Conflicts of Interest: The authors declare no conflict of interest. The funders had no role in the design of the study; in the collection, analyses, or interpretation of data; in the writing of the manuscript, or in the decision to publish the results.

\section{References}

1. Schmidt, R., III; Eguchi, T.; Austin, S.; Gibb, A. What is the meaning of adaptability in the building industry? In Proceedings of the CIB 16th International Conference on Open and Sustainable Building, Bilbao, Spain, 17-19 May 2010.

2. Arge, K. Adaptable office buildings: Theory and practice. Facilities 2005, 23, 119-127. [CrossRef]

3. Kelly, G.; Schmidt, R., III; Dainty, A.; Story, V. Improving the design of adaptable buildings through effective feedback in use. In Proceedings of the CIB Management and Innovation for a Sustainable Built Environment Conference, Amsterdam, The Netherlands, 20-23 June 2011. 
4. Sinclair, B.R.; Mousazadeh, S.; Safarzadeh, G. Agility, adaptability + appropriateness: Conceiving, Crafting \& constructing an architecture of the 21st century. ARCC J. 2012, 9, 35-43. [CrossRef]

5. Gosling, J.; Sassi, P.; Naim, M.; Lark, R. Adaptable buildings: A systems approach. Sustain. Cities Soc. 2013, 7, 44-51. [CrossRef]

6. Heidrich, O.; Kamara, J.M.; Maltese, S.; Cecconi, F.R.; Dejaco, M.C. A critical review of the developments in building adaptability. Int. J. Build. Pathol. Adapt. 2017, 35, 284-303. [CrossRef]

7. Gijsbers, I.R. Towards adaptability in structures to extend the functional lifespan of buildings related to flexibility in future use of space. In Proceedings of the 2006 International Conference on adaptable building structures (Adaptables 2006), Eindhoven, The Nederlands, 3-5 July 2006.

8. Webster, M.D. Structural design for adaptability and deconstruction: A strategy for closing the materials loop and increasing building value. In Proceedings of the ASCE Structures Congress: New Horizons and Better Practices, Long Beach, CA, USA, 16-19 May 2007; pp. 1-6.

9. Burak, R.; Hall, B.; Parker, K. Designing for adaptability, disassembly, and deconstruction. PCI J. 2010, 55, 40-43.

10. Schmidt, R.; Vibaek, K.S.; Austin, S. Evaluating the adaptability of an industrialized building using dependency structure matrices. Constr. Manag. Econ. 2014, 32, 160-182. [CrossRef]

11. Beadle, K.; Gibb, A.; Austin, S.; Fuster, A.; Madden, P. Adaptable futures: Setting the agenda? In Proceedings of the 1st I3CON International Conference; Loughborough University, Loughborough, UK, 14-16 May 2008.

12. Leaman, A. What is a Building for?: Part I. Facilities 1991, 9, 13-16. [CrossRef]

13. Leaman, A. What is a Building for?: Part II. Facilities 1991, 9, 16-19. [CrossRef]

14. Agha, R.H.; Kamara, J.M. Adaptations in traditional courtyard houses in Baghdad, Iraq. Int. J. Build. Pathol. Adapt. 2017, 34, 348-363. [CrossRef]

15. Harvey, J.; Heidrich, O.; Cairns, K. Psychological factors to motivate sustainable behaviours. Urban Des. Plan. 2014, 167, 165-174. [CrossRef]

16. Brand, S. How Buildings Learn: What Happens after They're Built; Viking Press: New York, NY, USA, 1994.

17. Pinder, J.; Schmidt-Iii, R.; Austin, S.; Gibb, A.; Saker, J. What is meant by adaptability in buildings? Facilities 2017, 35, 2-20. [CrossRef]

18. Re Cecconi, F.; Moretti, N.; Maltese, S.; Dejaco, M.C.; Kamara, J.M.; Heidrich, O. A rating system for building resilience. TECHNE 2018, 15, 358-365.

19. Foster, G.; Kreinin, H. A review of environmental impact indicators of cultural heritage buildings: A circular economy perspective. Environ. Res. Lett. 2020, 15, 043003. [CrossRef]

20. Kendall, S. Reflections on the History and Future of the Open Building Network, CIB W104 Open Building Implementation. 2015. Available online: http://open-building.org/archives/Reflections_on_the_History_ and_Future_of_Open\%20Building_and_the_OB_Network.pdf (accessed on 29 July 2020).

21. Scuderi, G. Designing flexibility and adaptability: The answer to integrated residential building retrofit. Designs 2019, 3, 3. [CrossRef]

22. Rockow, Z.R.; Ross, B.E.; Black, A.K. Review of methods for evaluating adaptability of buildings. Int. J. Build. Pathol. Adapt. 2019, 37, 273-287. [CrossRef]

23. Duffy, F. Measuring building performance. Facilities 1990, 8, 17. [CrossRef]

24. Schmidt, R., III; Austin, S. Adaptable Architecture: Theory and Practice; Routledge: Abingdon, Oxon, UK, 2016.

25. Maltese, S.; Kamara, J.M.; Dejaco, M.C.; Re Cecconi, F. Towards an adaptability rating for buildings. In Proceedings of the CIB International Conference, Leveraging Knowledge and Innovation for Sustainable Construction and Development, London, UK, 23-25 November 2015; pp. 319-329.

26. Pelsmakers, S.; Poutanen, J.; Saarimaa, S. 32 (Hybrid) architecture in and over time. In Ecologies Design: Transforming Architecture, Landscape, and Urbanism; Zari, M.P., Connolly, P., Southcombe, M., Eds.; CRC Press: Boca Raton, FL, USA, 2020.

27. Kyrö, R.; Peltokorpi, A.; Luoma-Halkola, L. Connecting adaptability strategies to building system lifecycles in hospital retrofits. Eng. Constr. Arch. Manag. 2019, 26, 633-647. [CrossRef]

28. By, R.T. Organisational change management: A critical review. J. Chang. Manag. 2005, 5, 369-380. [CrossRef]

29. Wilkinson, S.J. How buildings learn. Facilities 2014, 32, 382-395. [CrossRef]

30. Mendizabal, M.; Heidrich, O.; Feliu, E.; Garcia-Blanco, G.; Mendizabal, A. Stimulating urban transition and transformation to achieve sustainable and resilient cities. Renew. Sustain. Energy Rev. 2018, 94, 410-418. [CrossRef] 
31. Sun, M.; Meng, X. Taxonomy for change causes and effects in construction projects. Int. J. Proj. Manag. 2009, 27, 560-572. [CrossRef]

32. Bröchner, J.; Badenfelt, U. Changes and change management in construction and IT projects. Autom. Constr. 2011, 20, 767-775. [CrossRef]

33. Whyte, J.; Stasis, A.; Lindkvist, C. Managing change in the delivery of complex projects: Configuration management, asset information and 'big data'. Int. J. Proj. Manag. 2016, 34, 339-351. [CrossRef]

34. Leaman, A. The language of change. Facilities 1992, 10, 24. [CrossRef]

35. Thomson, T. Managing Change. Facilities 1992, 10, 19-23. [CrossRef]

36. Snodgrass, R.T. Temporal databases. In Theories and Methods of Spatio-Temporal Reasoning in Geographic Space, Proceedings of the International Conference GIS, Pisa, Italy, 21-23 September 1992; Frank, A.U., Campari, I., Formentini, U., Eds.; Springer: Berlin, Germany, 1992; pp. 22-64.

37. Schmidt, R., III; Sage, D.; Eguch, T.; Dainty, A. Moving architecture and flattening politics: Examining adaptability through a narrative of design. Arch. Res. Q. 2012, 16, 75-84. [CrossRef]

38. Worboys, M.F. Modelling changes and events in dynamic spatial systems with reference to socio-economic units. In Life and Motion of Socio-Economic Units: GISDATA; Frank, A.U., Raper, J., Cheylan, J.-P., Eds.; Taylor and Francis: London, UK, 2005; Volume 8, pp. 115-123.

39. Murdoch, J.; Hughes, W. Construction Contracts: Law and Management, 4th ed.; Taylor and Francis: Abingdon, UK, 2010.

40. Allen, D. What is building maintenance? Facilities 1993, 11, 7-12. [CrossRef]

41. Bullen, P.A. Adaptive reuse and sustainability of commercial buildings. Facilities 2007, 25, 20-31. [CrossRef]

42. Bullen, P.; Love, P.E.D. Factors influencing the adaptive re-use of buildings. J. Eng. Des. Technol. 2011, 9, 32-46. [CrossRef]

43. Haldi, F.; Robinson, D. On the behaviour and adaptation of office occupants. Build. Environ. 2008, 43, 2163-2177. [CrossRef]

44. Herkel, S.; Knapp, U.; Pfafferott, J. Towards a model of user behaviour regarding the manual control of windows in office buildings. Build. Environ. 2008, 43, 588-600. [CrossRef]

45. Stazi, F.; Naspi, F.; D'Orazio, M. A literature review on driving factors and contextual events influencing occupants' behaviours in buildings. Build. Environ. 2017, 118, 40-66. [CrossRef]

46. Chan, A.P. Modelling building durations in Hong Kong. Constr. Manag. Econ. 1999, 17, 189-196. [CrossRef]

47. Cambridge Dictionary. Available online: http://dictionary.cambridge.org/dictionary/english/decoration (accessed on 5 September 2017).

48. BS EN 13306:2010. Maintenance-Maintenance Terminology; British Standards Institution; British Standards Institution (BSI): London, UK, 2010.

49. Earnes, M.; Dixon, T.; Lannon, S.; Hunt, M.; de Laurentis, C.; Marvin, S.; Hodson, M.; Guthrie, P.; Georgiadoe, M. Retrofit 2050: Critical Challenges for Urban Transitions; Cardiff University: Cardiff, UK, 2014; ISBN 978-1-899895-12-0. Available online: http://www.retrofit2050.org.uk/retrofit-2050-report-criticalchallenges-urban-transitions (accessed on 12 December 2017).

50. Wing, C.K.; Raftery, J.; Walker, A. The baby and the bathwater: Research methods in construction management. Constr. Manag. Econ. 1998, 16, 99-104. [CrossRef]

51. Hunter, K.; Kelly, J. Grounded theory. In Advanced Research Methods in the Built Environment; Knight, A., Ruddock, L., Eds.; Wiley-Blackwell: Oxford, UK, 2008.

52. Yin, R.K. Case Study Research: Design and Methods; Sage Publications: Thousand Oaks, CA, USA, 2003.

53. Taylor, J.E.; Dossick, C.S.; Garvin, M.J. Meeting the burden of proof with case-study research. J. Constr. Eng. Manag. 2011, 137, 303-311. [CrossRef]

(C) 2020 by the authors. Licensee MDPI, Basel, Switzerland. This article is an open access article distributed under the terms and conditions of the Creative Commons Attribution (CC BY) license (http://creativecommons.org/licenses/by/4.0/). 